\title{
Evaluating the Environmental Impacts of Fluoride on the Growth and Physiology of Cotton (Gossypium hirsutum)
}

\section{Muhammad Nawaz ${ }^{*}$, Muhammad Dawood ${ }^{1}$, Kainat Javaid ${ }^{1}$, Muhammad Imran $^{2}$, Fengliang Zhao ${ }^{3}$, Shahzadi Saima ${ }^{4}$ and Syed Tansir Hussain Shah ${ }^{2}$}

${ }^{1}$ Department of Environmental Sciences, Bahauddin Zakariya University, Multan, Pakistan; ${ }^{2}$ Soil and water Testing Laboratory, Khanewal-58150, Punjab, Pakistan; ${ }^{3}$ Institute of Environmental and Plant Protection, Chinese Academy of Tropical Agriculture Science, Haikou, Hainan, China; ${ }^{4}$ Insitute of Pure and Applied Biology, Bahauddin Zakariya University, Multan, Pakistan.

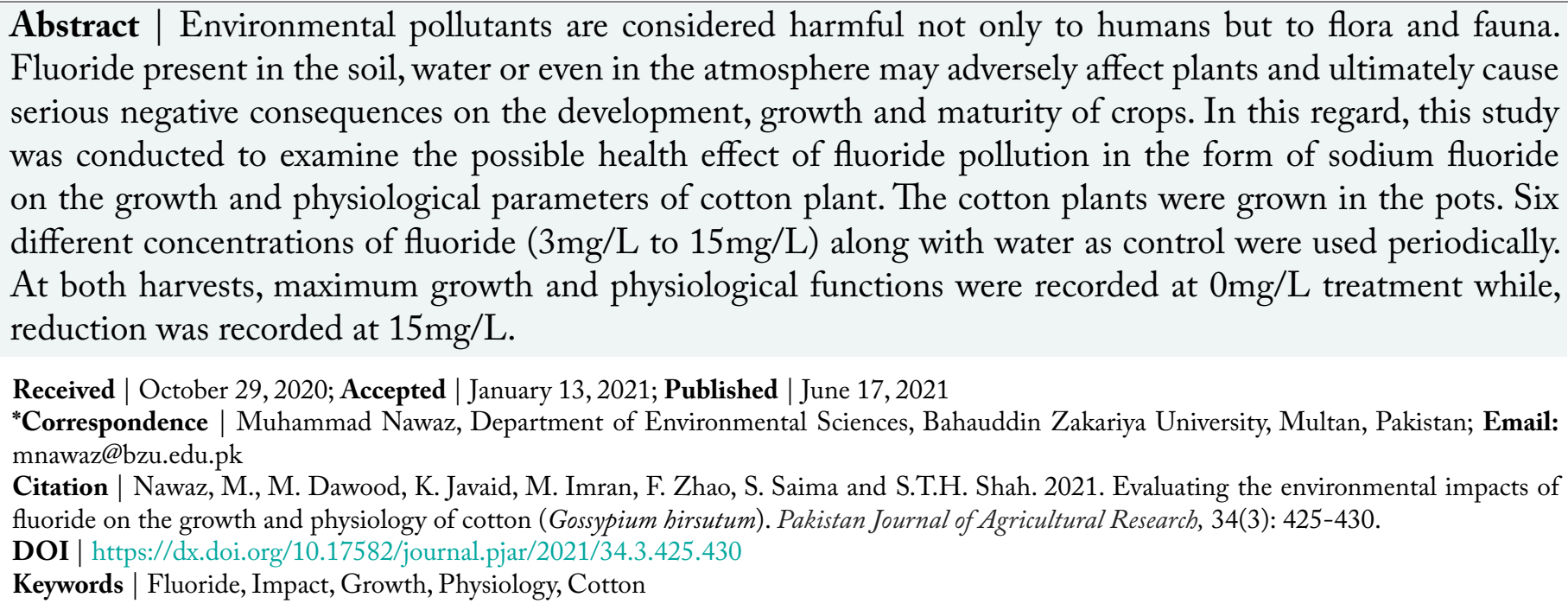

\section{Introduction}

$\mathrm{R}$ apid urbanization across the world increased industrialization which affected the environment through releasing the huge numbers of toxic pollutants. In all pollutants, fluoride $(\mathrm{F})$ ion is found the poisonous pollutant which has adverse effects on both biotic and a-biotic factor of environment (Pent et al., 2008; Dolottseva, 2013). According to the study of Dey et al. (2012) the major industries which release F into the environment are coal combustion, mining, aluminum manufacture and using $\mathrm{F}$ as a fertilizer. Further, the use of fluoride containing pesticides and water with fluoride contents also contributed to environmental pollution. Fluoride is well-known as highly phyto-toxic that easily diffuses in the soil and rapidly absorbed through plants roots when $\mathrm{pH}$ of the soil is more acidic (Mustafa et al., 2018).

There are two significant ways in which plants exposed to F (Alim et al., 2017; Dolottseva, 2013). Fluoride contents can also enter the body of plants through stomatal opening of plants for gaseous exchange through the cells and in the environment (Domingos et al., 2003). Fluoride enters the plant through leaves, penetrates the cell wall, and moves to the margins and leaf tip which are essential areas for the evaporation (Mustafa et al., 2018). Second exposure way is through the roots of plants. Roots absorb $\mathrm{F}$ from the soil (Mackowiak et al., 2003). Fluoride moves through xylematic flow to enter the leaves or stem of a plant. Although, stems are considered the least 
priority place for $\mathrm{F}$ to stay in plants (Kamaluddin et al., 2004).

The study of (Datta et al., 2012; Hong et al., 2016) revealed that fluoride pollution can produce the negative impacts on the growth and physiological functions of plants. The $\mathrm{F}$ ions inhibit germination, decrease plant's growth, reduces crop's yield, respiration, inhabit metabolism of protein and amino acid, reduce photosynthesis, chlorosis, necrosis and leaf tip burn, decrease in chlorophyll, damage to fruits.

Cotton which belongs to family malvaceae and genus Gossyoium is considered as most value able crop in the world because it is commercially important for producing the fibre in different countries including Pakistan (Cronn et al., 2002; Jiwen et al., 2012; Shuli et al., 2018). Cotton seeds are an important source of fibre, protein, oil, and considered like a nutrients ingredient in human food and animal feed products (Liu et al., 2009). It is also used as a renewable biofuel (Bellaloui et al., 2019; He et al., 2013). The main objective of this study was to examine the impacts of fluoride pollution on the biological functions of cotton crop.

\section{Materials and Methods}

The experiment was performed in Botanical Garden, Bahauddin Zakaryia University, Multan, during the season of 2019-2020. Certified cotton seeds were collected from the Horticulture department BZU, Multan. Under normal temperature, cotton seeds were germinated. Almost 10 seeds were sown in 50 earthen pots, which were filled with $4 \mathrm{~kg}$ of sandy loam soil. After 18 days of germination, two seedlings were allowed to grow in every pot. Total six groups viz: $0 \mathrm{mg} / \mathrm{L}$ was kept as control while $15 \mathrm{mg} / \mathrm{L}$ was set as maximum treatment of fluoride during the study with three replicates each. Each pot was placed in an open environment. On a daily basis, watering was done. Twice a week, solution of respective concentrations or amounts of sodium fluoride was given throughout an experimental period. First harvesting was done after 75 days and second harvesting was done after 110 days. At each harvest, six plants were taken. Growth and physiological parameters of plants were taken in to account during the research work to ensure the impacts of fluoride on the cotton crop. Statistical analysis was done by using ANOVA with LSD at $P \leq 0.05$.

\section{Results and Discussion}

Table 1 showed that $\mathrm{F}$ negatively affects the root growth parameters. All levels of treatment exhibited negative effects on the growth parameters in both harvests with the increase of Fluoride. At 1 harvest, maximum fresh and dry weight of root (14.733, 11.333 respectively), and length of root (4.02) were observed at $0 \mathrm{mg} / \mathrm{L}$ of fluoride application. While lowest fresh and dry weight of root $(10.67,6.33$ respectively) and length of root (2.517) were observed at $15 \mathrm{mg} / \mathrm{L}$ fluoride application. On the other hand, at 2 harvests; maximum (fresh weight of root 20.67), (dry weight of root 13.67) and (length of root 4.83) were recorded at $0 \mathrm{mgL}$ fluoride application. While lowest fresh, dry and length of root were observed $14.67,9.43,3.43$, respectively were observed at $15 \mathrm{mg} / \mathrm{L}$ fluoride application. Dey et al. (2012) found same findings while worked on the young seedlings of Bengal gram. Similarly, Sachan and Lal (2018) for Chickpea (Cicer arietinum L.) and barley (Hordeum vulgare L.). Onion (Allium cepa) was studied by Jha et al. (2009). Kamaluddin and Zwiazek (2003) for aspen seedling, Saini et al. (2008) for Prosopis juliflora and Pant et al. (2008) for wheat (Triticum aestivum), Table 2 revealed that $F$ negatively affects the shoot growth parameters. The results showed that all levels of $\mathrm{F}$ treatment indicated the reduction in growth parameters of plant. During the first harvest fresh and dry weight of shoot $(40,24.83 \mathrm{~cm}$, respectively) and length of shoot $(60 \mathrm{~cm})$ were observed maximum at $0 \mathrm{mg} / \mathrm{L}$ fluoride treatment. While reduced fresh weight of shoot $(20 \mathrm{~cm})$, dry weight of shoot (12.50) and length of shoot $(36.0 \mathrm{~cm})$ were observed at $15 \mathrm{mg} / \mathrm{L}$ fluoride treatment. On the other hand, during second harvest maximum fresh weight of shoot $(35 \mathrm{gm})$, dry weight of shoot $(28.50 \mathrm{gm})$ and length of shoot $(79.80 \mathrm{~cm})$ were observed at $0 \mathrm{mgL}$ fluoride application, while lowest value were found for shoot (fresh and dry weight) $25.67,18.866$, respectively for root and $(50.0 \mathrm{~cm})$ for length of shoot were observed at $15 \mathrm{mg} / \mathrm{L}$ fluoride application. Singh et al. (2017) revealed that increasing levels of fluoride decreased the shoot growth and shoot weight in barley and wheat. Similar results were obtained in Triticum aestivum var. Raj. 4083 (Bhargava and Bhardwaj 2010), Triticum aestivum, Cicer arietinum L. Brassica juncea and Lycopersicon esculentum (Pant et al., 2008), Cicer arientinum L. (Dey et al., 2012), Medicago sativa var. Anand-2 (Brahmbhatt and Patel, 2013). 
Table 1: Impact of various concentrations of fuoride on root fresh weight, roots dry weight and root length.

$\begin{array}{lllll}\text { Treatment } & \text { Harvest } & \text { RFW } & \text { RDW } & \text { RL } \\ 0 \mathrm{mg} / \mathrm{L} & 1 & 14.73 \mathrm{DE} & 11.33 \mathrm{C} & 4.03 \mathrm{D} \\ 3 \mathrm{mg} / \mathrm{L} & & 14.50 \mathrm{E} & 9.67 \mathrm{E} & 3.73 \mathrm{E} \\ 6 \mathrm{mg} / \mathrm{L} & & 13.47 \mathrm{EF} & 9.50 \mathrm{E} & 3.43 \mathrm{~F} \\ 9 \mathrm{mg} / \mathrm{L} & & 12.50 \mathrm{FG} & 8.60 \mathrm{~F} & 3.12 \mathrm{G} \\ 12 \mathrm{mg} / \mathrm{L} & & 11.67 \mathrm{GH} & 7.27 \mathrm{G} & 2.82 \mathrm{H} \\ 15 \mathrm{mg} / \mathrm{L} & & 10.67 \mathrm{H} & 6.33 \mathrm{H} & 2.52 \mathrm{I} \\ 0 \mathrm{mg} / \mathrm{L} & 2 & 20.67 \mathrm{~A} & 13.67 \mathrm{~A} & 4.83 \mathrm{~A} \\ 3 \mathrm{mg} / \mathrm{L} & & 18.33 \mathrm{~B} & 12.67 \mathrm{~B} & 4.63 \mathrm{~B} \\ 6 \mathrm{mg} / \mathrm{L} & & 18.30 \mathrm{~B} & 11.92 \mathrm{C} & 4.33 \mathrm{C} \\ 9 \mathrm{mg} / \mathrm{L} & & 17.43 \mathrm{BC} & 11.57 \mathrm{C} & 4.03 \mathrm{D} \\ 12 \mathrm{mg} / \mathrm{L} & & 16.30 \mathrm{CD} & 10.58 \mathrm{D} & 3.73 \mathrm{E} \\ 15 \mathrm{mg} / \mathrm{L} & & 14.67 \mathrm{E} & 9.43 \mathrm{E} & 3.43 \mathrm{~F} \\ \mathrm{HSD} & & 1.56 & 0.62 & 0.04\end{array}$

Table 2: Impact of various concentrations of fluoride on shoot fresh weight, shoots dry weight and shoot length.

$\begin{array}{lllll}\text { Treatment } & \text { Harvest } & \text { SFW } & \text { SDW } & \text { SL } \\ 0 \mathrm{mg} / \mathrm{L} & 1 & 40 \mathrm{~A} & 24.83 \mathrm{C} & 60.00 \mathrm{E} \\ 3 \mathrm{mg} / \mathrm{L} & & 37 \mathrm{~B} & 22.50 \mathrm{D} & 54.00 \mathrm{G} \\ 6 \mathrm{mg} / \mathrm{L} & & 32 \mathrm{D} & 21.80 \mathrm{D} & 48.00 \mathrm{I} \\ 9 \mathrm{mg} / \mathrm{L} & & 27.67 \mathrm{G} & 20.33 \mathrm{E} & 42.00 \mathrm{~J} \\ 12 \mathrm{mg} / \mathrm{L} & & 26 \mathrm{HI} & 18.50 \mathrm{~F} & 36.00 \mathrm{~K} \\ 15 \mathrm{mg} / \mathrm{L} & & 20 \mathrm{~J} & 12.50 \mathrm{G} & 32.00 \mathrm{~L} \\ 0 \mathrm{mg} / \mathrm{L} & 2 & 35 \mathrm{C} & 28.50 \mathrm{~A} & 79.80 \mathrm{~A} \\ 3 \mathrm{mg} / \mathrm{L} & & 33 \mathrm{D} & 26.17 \mathrm{~B} & 73.50 \mathrm{~B} \\ 6 \mathrm{mg} / \mathrm{L} & & 30.67 \mathrm{E} & 24.17 \mathrm{C} & 68.00 \mathrm{C} \\ 9 \mathrm{mg} / \mathrm{L} & & 29.33 \mathrm{~F} & 22.50 \mathrm{D} & 62.00 \mathrm{D} \\ 12 \mathrm{mg} / \mathrm{L} & & 27 \mathrm{GH} & 20.17 \mathrm{E} & 56.00 \mathrm{~F} \\ 15 \mathrm{mg} / \mathrm{L} & & 25.67 \mathrm{I} & 18.87 \mathrm{~F} & 50.00 \mathrm{H} \\ \mathrm{HSD} & & 1.2 & 1.09 & 0.81\end{array}$

Table 3 showed that application of $\mathrm{F}$ negatively affected the Leaf area and Phosphate starvation response (PSR). The results showed that all levels of $\mathrm{F}$ treatment indicated the reduction in leaves area and PSR at both harvest. Leaf area and PSR were gradually decreased as application level of fluoride increased. At first harvest, maximum Leaf area (4.80), and PSR (28.11) were observed at $0 \mathrm{mgL}$ Fluoride application. While lowest Leaf area (2.80), and PSR (17.07) were observed at $15 \mathrm{mg} / \mathrm{L} \mathrm{F}$ application. On the other hand, at 2 harvest Maximum Leaf area (6.90) and PSR (42.85) were observed at $0 \mathrm{mgL}$ Fluoride application, while lowest Leaf area (5.20) and PSR (31.98) were observed at $15 \mathrm{mg} / \mathrm{L} \mathrm{F}$ application. Similar results have also been demonstrated by Singh et al., (2013); Alim et al. (2017) and Ahmed et al. (2018); Elżbieta et al. (2020). According to Hong et al. (2016); Justyna et al. (2020) fluoride produced negative impacts on the morphology, physiology and even caused death of cells.

Table 3: Impact of various concentrations of fluoride on leaf area and photo synthetic rate.

$\begin{array}{llll}\text { Treatment } & \text { Harvest } & \text { LA } & \text { PSR } \\ 0 \mathrm{mg} / \mathrm{L} & 1 & 4.80 \mathrm{G} & 28.11 \mathrm{G} \\ 3 \mathrm{mg} / \mathrm{L} & & 4.40 \mathrm{H} & 26.10 \mathrm{H} \\ 6 \mathrm{mg} / \mathrm{L} & & 4.00 \mathrm{I} & 24.09 \mathrm{I} \\ 9 \mathrm{mg} / \mathrm{L} & & 3.60 \mathrm{~J} & 22.09 \mathrm{~J} \\ 12 \mathrm{mg} / \mathrm{L} & & 3.20 \mathrm{~K} & 19.98 \mathrm{~K} \\ 15 \mathrm{mg} / \mathrm{L} & & 2.80 \mathrm{~L} & 17.07 \mathrm{~L} \\ 0 \mathrm{mg} / \mathrm{L} & 2 & 6.90 \mathrm{~A} & 42.85 \mathrm{~A} \\ 3 \mathrm{mg} / \mathrm{L} & & 6.60 \mathrm{~B} & 40.77 \mathrm{~B} \\ 6 \mathrm{mg} / \mathrm{L} & & 6.30 \mathrm{C} & 38.47 \mathrm{C} \\ 9 \mathrm{mg} / \mathrm{L} & & 6.00 \mathrm{D} & 36.20 \mathrm{D} \\ 12 \mathrm{mg} / \mathrm{L} & & 5.60 \mathrm{E} & 34.09 \mathrm{E} \\ 15 \mathrm{mg} / \mathrm{L} & & 5.20 \mathrm{~F} & 31.98 \mathrm{~F} \\ \mathrm{HSD} & & 0.55 & 8.50\end{array}$

In this study, it has been found that fluoride affected the germination \% age, growth and physiological attributes of cotton. During all levels of $\mathrm{F}$ treatments, all parameters of plant were reduced significantly. All parameters showed maximum increase at control treatment which is omg/L and with lowest at $15 \mathrm{mg} / \mathrm{L}$ of treatment. Similar result was obtained in different plants (Chakrabarti et al., 2012; Singh et al., 2013; Fina et al., 2016; Hong et al., 2016; Ahmed et al., 2018) found such reduced results under the negative influence of fluoride in wheat, rice and barely.

Our results also showed that the fluoride application affected the chlorophyll a and chlorophyll $b$. The results showed that all levels of fluoride treatment indicated the decrease in the chlorophyll a and $\mathrm{b}$ at both harvests. Chlorophyll a and chlorophyll b were gradually decreased as application level of fluoride increased. At both harvests, maximum chlorophyll $a$ and chlorophyll b were observed at $0 \mathrm{mgL}$ of treatment of fluoride application. While lowest chlorophyll a and b was found at $15 \mathrm{mg} / \mathrm{L}$ fluoride application. According to many Authors (Elloumi et al., 2005; Sabal et al., 2006; Bhargava and Bhardwaj, 2010; Dey et al., 2012; Chandra et al., 2012; Barnwal 
et al., 2019) when plants were treated with different concentrations of fluoride, then it was found that chlorophyll a and chlorophyll b were decreased.

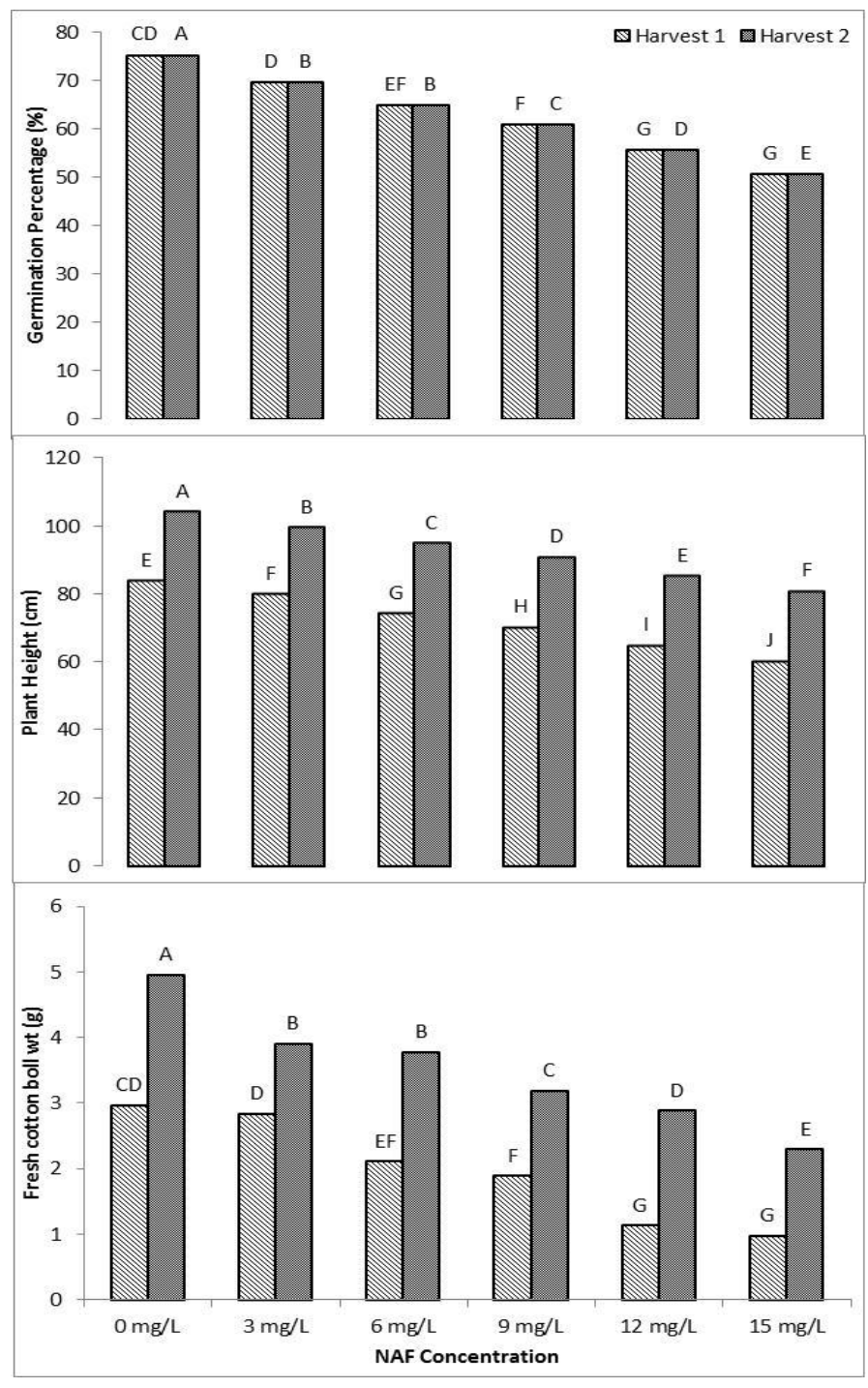

Figure 1: Effect of NaF on the germination percontage, plant height and fresh cotton boll.

\section{Acknowledgements}

We are very thankful to the director and team of Soil and water Testing Laboratory, Khanewal for helping in sample analysis.

\section{Novelty Statement}

Now a day environmental pollution is one of the big problems for health of living organisms, so this research work highlights the need of reducing fluoride emission which is big curse for crops. This work also orients the way of entry of fluoride in crops and reduces the growth.

\section{Author's Contribution}

Muhammad Nawaz: Overall planned and handling. Muhammad Dawood: Statistical analysis.

Kainat Javaid: Collected data and maintained data. Muhammad Imran: Helped in sample analysis.

Fengliang Zhao: Critical discussion.

Shahzadi Saima: Designed and looked after the experiment.

Syed Tansir Hussain Shah: Helped in laboratory.

\section{Conflict of interest}

The authors have declared no conflict of interest.

\section{References}

Ahmad, M.A., H. Bibi, I. Munir, M.N. Ahmad, A. Zia, G. Mustafa and I. Khan. 2018. Fluoride toxicity and its effect on two varieties of Solanum lycopersicum. Fluoride, 51(3): 267-277.

Alim, H., M.A. Ahmad, I. Munir, I. Khan, G. Mustafa, I. Ullah and I. Khan. 2017. The effect of different concentrations of the fluoride ion on the growth and nutritional value of two elite genotypes of Triticum estivum. Fluoride, 50(1): 143.

Barnwal, P., P. Kore and A. Sharma. 2019. Effect of partially de-oiled maize germ cake flour on physico-chemical and organoleptic properties of biscuits. J. Food Pro.and Tech.4:221-226.

Bellaloui, N., R.B. Turley, S.R. Stetina and W.T. Molin. 2019. Cottonseed protein, oil, and mineral nutrition in near-isogenic Gossypium birsutum cotton lines expressing leaf color phenotypes under field conditions. Food Nutr. Sci., 10(7): 834-859. https://doi.org/10.4236/ fns.2019.107061

Bhargava, D. and N. Bhardwaj. 2010. Effect of sodium fluoride on seed germination and seedling growth of Triticumaestivum Var. Raj. 4083. J. Phytol., 2(4): 41-43.

Brahmbhatt, N.H. and R.V. Patel. 2013. Effect of sodium flouride and magnesium chloride and its interaction on seedling growth of Medicagosativa, Anand, Gujarat. Asian J. Agric. Sci., 3(3): 80-84.

Chandra, P., N. Vishnoi and D.P. Singh. 2012. Assessment of fluoride contamination of water and soil and its phytotoxic effect on the growth parameters in selected vegetable crops. Glob. J. Appl. Environ. Sci., 2(1): 55-65.

Chakrabarti,S.,P.Liehl,N.Buchon, and B.Lemaitre. 
2012. Infection-Induced Host Translational Blockage Inhibits Immune Responses and Epithelial Renewal in the Drosophila Gut. Cell Host and Microbe. 12: 60-70.

Cronn, R.C., R.L. Small, T. Haselkorn and J.F. Wendel. 2002. Rapid diversification of the cotton genus (Gossypium: Malvaceae) revealed by analysis of sixteen nuclear and chloroplast genes. Am. J. Bot., 89(4): 707-725. https://doi. org/10.3732/ajb.89.4.707

Datta,J.K.,A.Maitra,N.K.Mondal and A.Banerjee. 2012. Studies on the impact of fluoride toxicity on germination and seedling growth of gram seed (Cicerarietinum L. cv. Anuradha). J. Stress Physiol. Biochem., 8(1): 194-202.

Dey, U., N.K. Mondal, K. Das and J.K. Datta. 2012. Dual effects of fluoride and calcium on the uptake of fluoride, growth physiology, pigmentation, and biochemistry of Bengal gram seedlings (Cicer arietinum L.). Fluoride, 45(4): 389-393.

Dolottseva, I.M., 2013. Effects of environmental fluoride on plants, animals and humans. Інтернет-конференції ХНУМГ ім.ОМ Бекетова, (1): 48-54.

Domingos, M., A. Klumpp, M.C.S. Rinaldi, I.F. Modesto, G. Klumpp and W.B.C. Delitti. 2003. Combined effects of air and soil pollution by fluoride emissions on Tibouchinapulchra Cogn., at Cubatão, SE Brazil, and their relations with aluminium. Plant Soil, 249(2): 297-308. https://doi.org/10.1023/A:1022800225753

Elloumi, N., F.B. Abdallah, I. Mezghani, A. Rhouma, M. Boukhris and S. Tunisia. 2005. Effect of fluoride on almond seedlings in culture solution. Fluoride, 38(3): 193.

Elżbieta, B., B. Antoni and R. Katarzyna. 2020. The influence of environmental pollution with fluorine compounds on the level of fluoride in soil, feed and eggs of laying hens in Central Pomerania. Poland Environ. Monit. Assess., 3(2020): 178-192. https://doi.org/10.1007/ s10661-020-8143-3

Fina, B.L., M. Lupo, N. Dri, M. Lombarte and A. Rigalli. 2016. Comparison of fluoride effects on germination and growth of Zea mays, Glycine max and Sorghum vulgare. J. Sci. Food Agric., 96(11): 3679-3687. https://doi.org/10.1002/ jsfa.7551

He, Z., M. Shankle, H. Zhang, T.R. Way, H. Tewolde and M. Uchimiya. 2013. Mineral
Composition of Cotton Seed Is Affected by Fertilization Management Practices. Agron. J., 105: 341-350. https://doi.org/10.2134/ agronj2012.0351

Hong, B.D., R.N. Joo, K.S. Lee, D.S. Lee,J.H. Rhie, S.W. Min and D.Y. Chung. 2016. Fluoride in soil and plant. Korean J. Agric. Sci., 43(4): 522536.

Jiwen, Y., Y. Shuxun, F. Shuli, S. Meizhen, Z. Honghong, L. Xingli and Z. Jinfa. 2012. Mapping quantitative trait loci for cottonseed oil, protein and gossypol content in a Gossypium birsutum Gossypium barbadense backcross inbred line population. Euphytica. 187:191-201. DOI 10.1007/s10681-012-0630-3.

Jha, S.K., A.K. Nayak and Y.K. Sharma. 2009. Fluoride toxicity effects in onion (Allium cepa L.) grown in contaminated soils. Chemosphere, 76(3): 353-356. https://doi.org/10.1016/j. chemosphere.2009.03.044

Justyna, P., S. Martyna, W. Jacek and T. Arkadiusz. 2020. Effect of Fluoride on germination, early growth and antioxidant enzymes activity of three winter wheat (Triticum aestivum L.) Cultivars. Appl. Sci., 10(2020): 69-71. https:// doi.org/10.3390/app10196971

Kamaluddin, M. and J.J. Zwiazek. 2003. Fluoride inhibits root water transport and affects leaf expansion and gas exchange in aspen (Populustremuloides) seedlings. Physiol. Plant., 117(3): 368-375. https://doi.org/10.1034/ j.1399-3054.2003.00040.x

Kamaluddin, M. and J.J. Zwiazek. 2004. Effects of root medium $\mathrm{pH}$ on water transport in paper birch (Betulapapyrifera) seedlings in relation to root temperature and abscisic acid treatments. Tree Physiol., 24(10): 1173-1180. https://doi. org/10.1093/treephys/24.10.1173

Liu, Q. S.P. Singh, K. Chapman and A.G. Green. 2009. Bridging traditional and molecular genetics in modifying cottonseed oil. In: Paterson, A.H., Ed., Genetics and Genomics of Cotton, Plant Genetics and Genomics: Crops and Models, 3, Springer, New York, pp. 353-382. https://doi.org/10.1007/978-0-38770810-2_15

Mackowiak, C.L., P.R. Grossl and B.G. Bugbee. 2003. Biogeochemistry of fluoride in a plant solution system. J. Environ. Qual., 32(6): 22302237. https://doi.org/10.2134/jeq2003.2230

Miller, G.W., 1993. The effect of fluoride on higher 
plants. Fluoride, 26: 3-22.

Mohan, L.S., R. Saini, S. Roy and A. Kumar. 2008. Comparative pharmacognostical and antimicrobial studies of acacia species (Mimosaceae) J. Med. Plants Res., 2(12): 378386.

Mustafa, G., I. Ullah and I. Khanc. 2018. Fluoride toxicity and its effects on two varieties of Solanum lycopersicum. Fluoride. 51(3): 267-277.

Pant, S., P. Pant and P.V. Bhiravamurthy. 2008. Effects of fluoride on early root and shoot growth of typical crop plants of India. Fluoride, 41(1): 57.

Sabal, D., T.L. Khan and R. Saxena. 2006. Effect of sodium fluoride on cluster bean (Cyamopsistetr agonoloba) seed germination and seedling growth. Fluoride, 39(3): 228.

Sachan, P. and N. Lal. 2018. Effect of sodium fluoride on germination, seedling growth and photosynthetic pigments in Cicer arietinum L. and Hordeum vulgare L. Moj. Ecol. Environ. Sci., 3: 300-304. https://doi.org/10.15406/ mojes.2018.03.00103

Saini, P., S. Khan, M. Baunthiyal and V. Sharma. 2012. Organ-wise accumulation of fluoride in Prosopis juliflora and its potential for phytoremediation of fluoride contaminated soil. Chemosphere, 89(5): 633-635. https://doi. org/10.1016/j.chemosphere.2012.05.034

Shuli, F., A.H. Jarwar, X. Wang, L. Wang and Q. Ma. 2018. Overview of the cotton in Pakistan and its future prospects. Pak. J. Agric. Res., 31(4): 396. https://doi.org/10.17582/journal. pjar/2018/31.4.396.407

Singh, S., J. Singh and N. Singh. 2013. Studies on the impact of fluoride toxicity on growth parameters of Raphanus sativus L. Indian J. Sci. Res., 4(1): 61-63.

Singh, U.P., R.B. Yashu, R. Sodani and J.P. Srivastava. 2017. Effect of elevated fluoride levels on morph-physiological parameters of wheat and barley. J. Pharmacogn. Phytochem., 6(6): 2245-2248. 